\title{
Methodology for assessing the resources of an industrial enterprise based on the concept of sustainable development
}

\author{
Svetlana Orekhova, and M. Zavialova* \\ Ural State University of Economics, st. 8 March / Narodnaya Volya, 62/45, 620144 Yekaterinburg, \\ Russia
}

\begin{abstract}
The article presents an original method for assessing the resources of an industrial enterprise based on the concept of sustainable development. The main emphasis in the assessment is made on the compliance of the enterprise resources with the principles of social, environmental and economic efficiency. The quality of human, investment, production and financial resources of industrial enterprises was assessed through the prism of established optima, the principles of resource conservation and resource efficiency. The proposed methodology will make it possible to develop a resource strategy that implements the principles of the concept of sustainable development and ECG management. Improvement of the resource strategy is aimed at eliminating the gaps in the quality of the enterprise resources.
\end{abstract}

\section{Introduction}

Industrial enterprises, due to the specifics of production and the sectoral markets in which they operate, are forced to withstand international competition. A fundamentally important condition for the formation of competitive advantages for industrial enterprises is to follow the principles of sustainable development, and its part - ECG-management [1]. High resource dependence, excessive consumption of natural resources by industrial enterprises depletes the reserves of minerals, and the technological backwardness of production significantly increases the volumes of solid and liquid emissions and wastes that harm the environment [2].

For the first time, the concept of sustainable development from the point of view of the ecological component was discussed in 1972 at the conference in Stockholm. In 1987, the concept of sustainable development was included in the report "Our Common Future" and it involved meeting the needs of people without harming the livelihoods of the future generation [3]. The UN World Conservation Strategy in 1990 advocates the conservation of natural resources [4]. Responsibility for the preservation and protection of the environment is proclaimed in the International Declaration of the Earth Charter, developed in 2000 by UNESCO [5].

The negative consequences of the global financial and economic crisis in 2008 increased the awareness of the triad of socio-ecological and economic development [6,7]. Thus, the study of economic, environmental and social problems is characterized by three periods of 
development: 1972-1990. (environmental sustainability), 1990-2008 (environmental and economic sustainability), 2008 - present (socio-ecological and economic sustainability). At the present stage, for the transition to energy-, resource-saving, waste-free production, the use of digital technologies in production is of great importance: the development of artificial intelligence, digital platforms, high-tech technologies, production automation, threedimensional printing, carbon-free energy, etc. [8].

The aim of the study is to develop a methodology for assessing the resources of an industrial enterprise based on the concept of sustainable development. An analysis of the company's resources for compliance with the principles and ideas of sustainable development will allow working out a resource strategy aimed at achieving sustainable competitive advantages.

\section{Methodology for assessing the resources of an industrial enterprise based on the concept of sustainable development}

Systematizing the approaches to the resources of an industrial enterprise [9-13], four groups of resources were identified that affect the implementation of the principles of sustainable development: human, investment, production and financial.

The author's methodology for assessing the resources of an industrial enterprise based on the concept of sustainable development involves identifying assessment metrics and correlating them with the type of sustainability (Table 1).

Table 1. The author's methodology for assessing the resources of an industrial enterprise based on the concept of sustainable development $[9,10,11,12]$

\begin{tabular}{|c|c|c|c|c|c|c|c|}
\hline \multirow{3}{*}{ 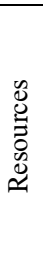 } & \multirow{3}{*}{$\begin{array}{c}\text { Type of } \\
\text { sustainabil } \\
\quad \text { ity }\end{array}$} & \multirow{3}{*}{ Goal } & \multirow{3}{*}{ Indicators } & \multirow{3}{*}{ Formula } & \multicolumn{3}{|c|}{$\begin{array}{l}\text { Evaluation of the indicator } \\
\text { from the point of view of } \\
\text { sustainable development } \\
\left(k_{n}\right)\end{array}$} \\
\hline & & & & & $\begin{array}{c}\text { Negati } \\
\text { ve }\end{array}$ & $\begin{array}{c}\text { Neutr } \\
\text { al }\end{array}$ & $\begin{array}{c}\text { Positi } \\
\text { ve }\end{array}$ \\
\hline & & & & & 1 point & $\begin{array}{c}2 \\
\text { points }\end{array}$ & $\begin{array}{c}3 \\
\text { points }\end{array}$ \\
\hline \multirow{6}{*}{ 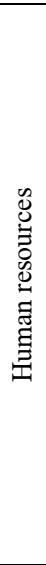 } & Economic & Ensure job & Job stability & BSC per the year worked & $0,4-0,6$ & $0,6-$ & $0,8-1$ \\
\hline & Social & stability & indicator & BSC general & $0,4-0,0$ & & \\
\hline & Economic & Provide & The rate of & Eof higher education sto & & & \\
\hline & & $\begin{array}{l}\text { highly } \\
\text { qualified } \\
\text { staff }\end{array}$ & $\begin{array}{c}\text { change in the } \\
\text { structure of } \\
\text { highly } \\
\text { qualified } \\
\text { personnel }\end{array}$ & Headcount & $\begin{array}{c}\text { More } \\
\text { than } \\
0,2\end{array}$ & $\begin{array}{c}0,2- \\
0,4\end{array}$ & $\begin{array}{c}\text { More } \\
\text { than } \\
0,4\end{array}$ \\
\hline & Social & $\begin{array}{c}\text { Provide a } \\
\text { safe } \\
\text { working } \\
\text { environmen } \\
\mathrm{t} \\
\end{array}$ & Injury rate & $\frac{\sum \text { accidents }}{\text { Headcount }}$ & $\begin{array}{l}\text { More } \\
\text { than } \\
0,2\end{array}$ & $\begin{array}{c}0,01- \\
0,2\end{array}$ & $\begin{array}{l}\text { Less } \\
\text { than } \\
0,01\end{array}$ \\
\hline & $\begin{array}{c}\text { Economic } \\
\text { Social }\end{array}$ & $\begin{array}{l}\text { Increase the } \\
\text { production } \\
\text { efficiency }\end{array}$ & $\begin{array}{l}\text { Labor } \\
\text { productivity } \\
\text { change } \\
\text { coefficient }\end{array}$ & $\begin{array}{c}\text { labor efficiency } \\
\text { for the period } \\
\text { labor efficiency } \\
\text { for the previous period }\end{array}$ & $\begin{array}{l}\text { Less } \\
\text { than } \\
0,7\end{array}$ & $0,7-1$ & $\begin{array}{l}\text { More } \\
\text { than } 1\end{array}$ \\
\hline & $\begin{array}{l}\text { Economic } \\
\text { Social } \\
\text { Ecological }\end{array}$ & $\begin{array}{c}\text { Involve } \\
\text { employees } \\
\text { in } \\
\text { innovations } \\
\text { developmen } \\
\mathrm{t}\end{array}$ & $\begin{array}{l}\text { Share of } \\
\text { employees } \\
\text { engaged in } \\
\text { R\&D }\end{array}$ & $\frac{\sum \text { of staff in } \mathrm{R} \& \mathrm{D}}{\text { Headcount }}$ & $\begin{array}{l}\text { Less } \\
\text { than } \\
0,005\end{array}$ & $\begin{array}{c}0,005 \\
-0,1\end{array}$ & $\begin{array}{c}\text { More } \\
\text { than } \\
0,1\end{array}$ \\
\hline
\end{tabular}


Table 1. Continued

\begin{tabular}{|c|c|c|c|c|c|c|c|}
\hline \multirow{3}{*}{ 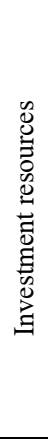 } & $\begin{array}{l}\text { Economic } \\
\text { Ecological }\end{array}$ & $\begin{array}{l}\text { Increase the } \\
\text { share of } \\
\text { investment } \\
\text { in fixed } \\
\text { assets using } \\
\text { own funds }\end{array}$ & $\begin{array}{l}\text { Fixed capital } \\
\text { investment } \\
\text { ratio }\end{array}$ & $\frac{\text { owned capital }}{\text { non-current assets }}$ & $\begin{array}{c}\text { Less } \\
\text { than } \\
0,6\end{array}$ & $0,6-1$ & $\begin{array}{l}\text { More } \\
\text { than } 1\end{array}$ \\
\hline & $\begin{array}{l}\text { Economic } \\
\text { Ecological }\end{array}$ & $\begin{array}{l}\text { Increase the } \\
\text { level of } \\
\text { technologie } \\
\text { s used }\end{array}$ & $\begin{array}{l}\text { Financial } \\
\text { investment } \\
\text { ratio }\end{array}$ & $\begin{array}{c}\text { owned capital }+ \\
\text { long - term liabilities } \\
\text { balance sheet total }\end{array}$ & $\begin{array}{c}\text { Less } \\
\text { than } \\
0,6\end{array}$ & $0,6-1$ & $\begin{array}{l}\text { More } \\
\text { than } 1\end{array}$ \\
\hline & $\begin{array}{l}\text { Economic } \\
\text { Ecological }\end{array}$ & $\begin{array}{c}\text { Develop } \\
\text { new types } \\
\text { of products }\end{array}$ & $\begin{array}{l}\mathrm{R} \& \mathrm{D} \\
\text { investment } \\
\text { ratio }\end{array}$ & $\frac{R \& D \text { costs }}{\text { sales volume }}$ & $\begin{array}{c}\text { Less } \\
\text { than } \\
0,5\end{array}$ & $0,5-1$ & $\begin{array}{l}\text { More } \\
\text { than } 1\end{array}$ \\
\hline \multirow{8}{*}{ 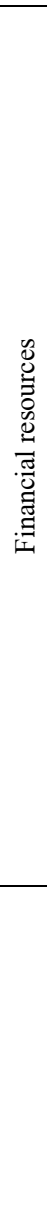 } & Economic & \multirow[t]{2}{*}{$\begin{array}{l}\text { Increase } \\
\text { financial } \\
\text { dependence }\end{array}$} & $\begin{array}{l}\text { Autonomy } \\
\text { ratio }\end{array}$ & $\frac{\text { owned capital }}{\text { capital assets }}$ & $\begin{array}{c}\text { Less } \\
\text { than } \\
0,3 \\
\end{array}$ & $\begin{array}{l}0,3- \\
0,5\end{array}$ & $\begin{array}{c}\text { More } \\
\text { than } \\
0,5\end{array}$ \\
\hline & Economic & & $\begin{array}{l}\text { Owned } \\
\text { capital } \\
\text { maneuverabil } \\
\text { ity ratio }\end{array}$ & $\frac{\text { current assets }}{\text { owned capital }}$ & $\begin{array}{c}\text { Less } \\
\text { than } \\
0,2\end{array}$ & $\begin{array}{l}0,2- \\
0,3\end{array}$ & $\begin{array}{l}0,3- \\
0,5\end{array}$ \\
\hline & Economic & \multirow[t]{2}{*}{$\begin{array}{l}\text { Ensure a } \\
\text { balanced } \\
\text { distribution } \\
\text { of financial } \\
\quad \text { flows }\end{array}$} & $\begin{array}{c}\text { Financial } \\
\text { stability ratio }\end{array}$ & $\begin{array}{l}\text { owned capital } * \\
\text { long } \\
\frac{\text {-term loans }}{\text { balance sheet total }}\end{array}$ & $\begin{array}{c}\text { Less } \\
\text { than } \\
0,5\end{array}$ & $\begin{array}{l}0,5- \\
0,7\end{array}$ & $\begin{array}{c}\text { More } \\
\text { than } \\
0,7\end{array}$ \\
\hline & Economic & & Equity ratio & $\frac{\text { Equity ratio }}{\text { Provision of funds }}$ & $\begin{array}{l}\text { Less } \\
\text { than } 0\end{array}$ & $0-0,1$ & $\begin{array}{c}\text { More } \\
\text { than } \\
0,1 \\
\end{array}$ \\
\hline & Economic & \multirow{2}{*}{$\begin{array}{l}\text { Increase the } \\
\text { ability to } \\
\text { pay debt of } \\
\text { the } \\
\text { enterprise }\end{array}$} & $\begin{array}{c}\text { Current } \\
\text { liquidity ratio }\end{array}$ & $\frac{\text { current assets }}{\text { short }- \text { term liabilities }}$ & $\begin{array}{l}\text { Less } \\
\text { than } 1\end{array}$ & $1-1,5$ & $\begin{array}{l}1,5- \\
2,5\end{array}$ \\
\hline & $\begin{array}{l}\text { Economic } \\
\text { Social }\end{array}$ & & $\begin{array}{l}\text { Solvency } \\
\text { ratio }\end{array}$ & $\begin{array}{c}\text { Owned capital / (term } \\
\text { liabilities + fixed assets }+ \\
\text { long-term liabilities) }\end{array}$ & $\begin{array}{c}\text { Less } \\
\text { than } \\
0,2\end{array}$ & $\begin{array}{c}0,2- \\
0,3\end{array}$ & $\begin{array}{c}0,3- \\
0,5\end{array}$ \\
\hline & Economic & $\begin{array}{l}\text { Optimize } \\
\text { the } \\
\text { manufacturi } \\
\text { ng process }\end{array}$ & $\begin{array}{c}\text { Product } \\
\text { profitability }\end{array}$ & $\frac{\text { Product }}{\text { production cost }}$ & $\begin{array}{c}\text { Less } \\
\text { than } \\
0,5\end{array}$ & $0,5-1$ & $\begin{array}{l}\text { More } \\
\text { than } 1\end{array}$ \\
\hline & $\begin{array}{l}\text { Economic } \\
\text { Ecological }\end{array}$ & $\begin{array}{l}\text { Increase the } \\
\text { production } \\
\text { capacity of } \\
\text { the basic } \\
\text { production } \\
\text { asset, } \\
\text { redesign the } \\
\text { basic } \\
\text { production } \\
\text { asset }\end{array}$ & $\begin{array}{l}\text { Return on } \\
\text { assets ratio }\end{array}$ & $\begin{array}{c}\text { price ofproduction } \\
\text { per year } \\
\text { average annual cost } \\
\text { of basic production } \\
\text { assets }\end{array}$ & $\begin{array}{c}\text { Less } \\
\text { than } \\
0,1\end{array}$ & $\begin{array}{l}0,1- \\
0,2\end{array}$ & $\begin{array}{c}\text { More } \\
\text { than } \\
0,2\end{array}$ \\
\hline
\end{tabular}


Table 1. Continued.

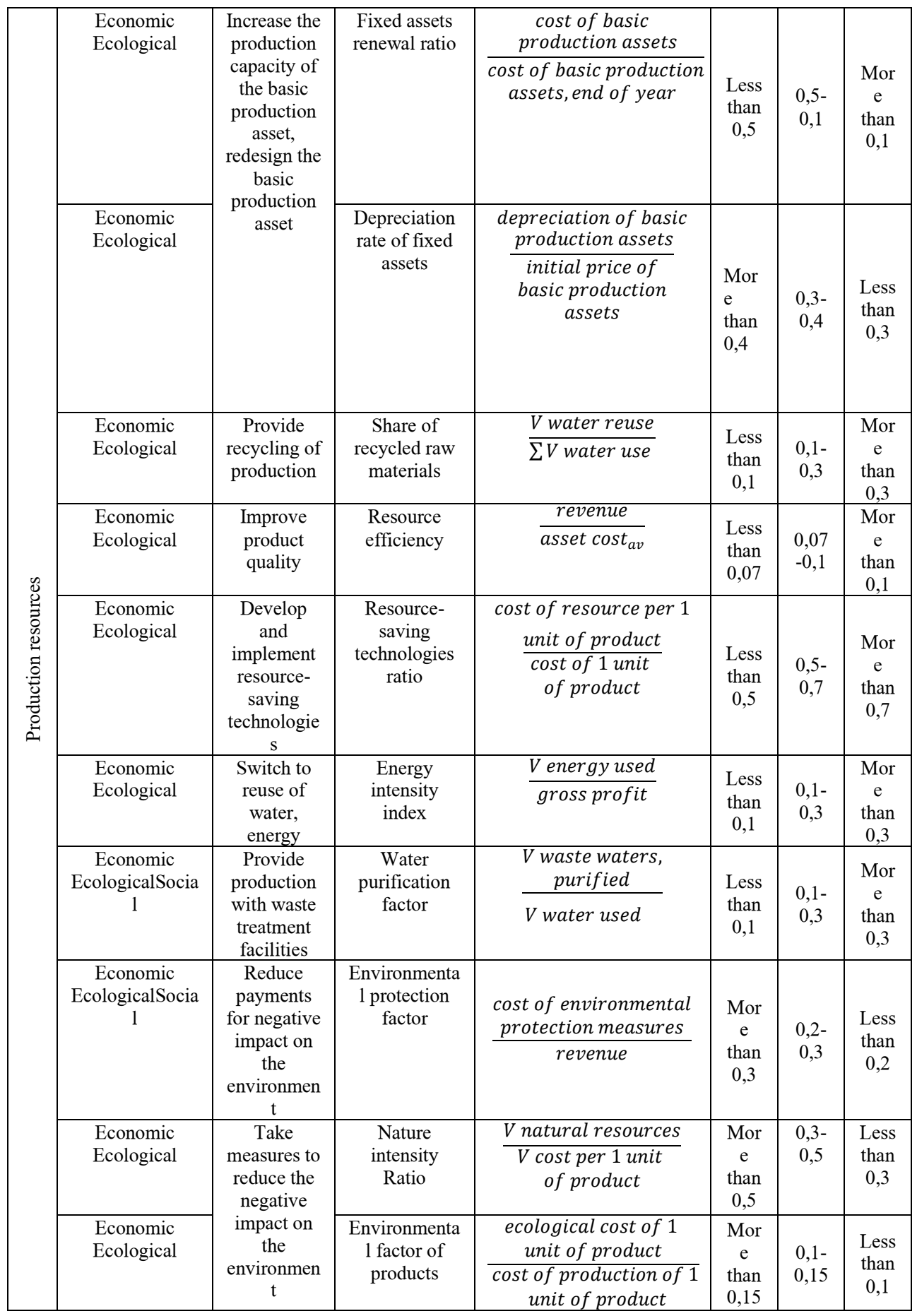

At the first stage, individual indicators are calculated, which make it possible to assess the resources of an industrial enterprise from the standpoint of the attainability of sustainable development goals. Due to the fact that the indicators for assessing the resources of an 
industrial enterprise differ, the authors proposed an interpretation of the results in the form of a point assessment of the indicator of sustainable development from 1 to 3 points. This will make it possible to bring individual indicators of resource assessment to a single value.

At the second stage, a generalized indicator is calculated for each studied resource group

$$
k_{\text {generalized resource }}=\sum k_{n 1, n 2, n 3, \ldots n_{p}}
$$

where $k_{\text {generalized }}$ - is a generalized indicator for assessing the resources of an industrial enterprise, $\mathrm{k} \_\left(\mathrm{n} 1, \mathrm{n} 2, \mathrm{n} 3, \ldots \mathrm{n} \_\mathrm{p}\right)$ - is the value of the point assessment of each indicator from the standpoint of the concept of sustainable development.

The higher the generalized indicator of the assessment of each investigated resource is, the more efficiently resources with economic, environmental, social sustainability are formed and used.

At the third stage, a complex indicator for assessing the resources of an industrial enterprise is calculated.

$$
k_{\text {complex resource }}=\sum k_{\text {generalized resource }}
$$

The study of a complex indicator for assessing the human, investment, production, and financial resources of an industrial enterprise in dynamics makes it possible to identify key problems that impede the achievement of sustainable development goals.

\section{Results and discussion}

Due to the high resource dependence of industrial enterprises, the achievement of a strategic goal requires the development of a resource strategy. The resource strategy is a strategic plan for the formation and use of resources, aimed at the transition to resource-saving, waste-free production in order to increase the economic, environmental and social sustainability of an industrial enterprise.

Figure 1 shows an algorithm for the formation of a resource strategy for an industrial enterprise, which includes the implementation of three blocks. 

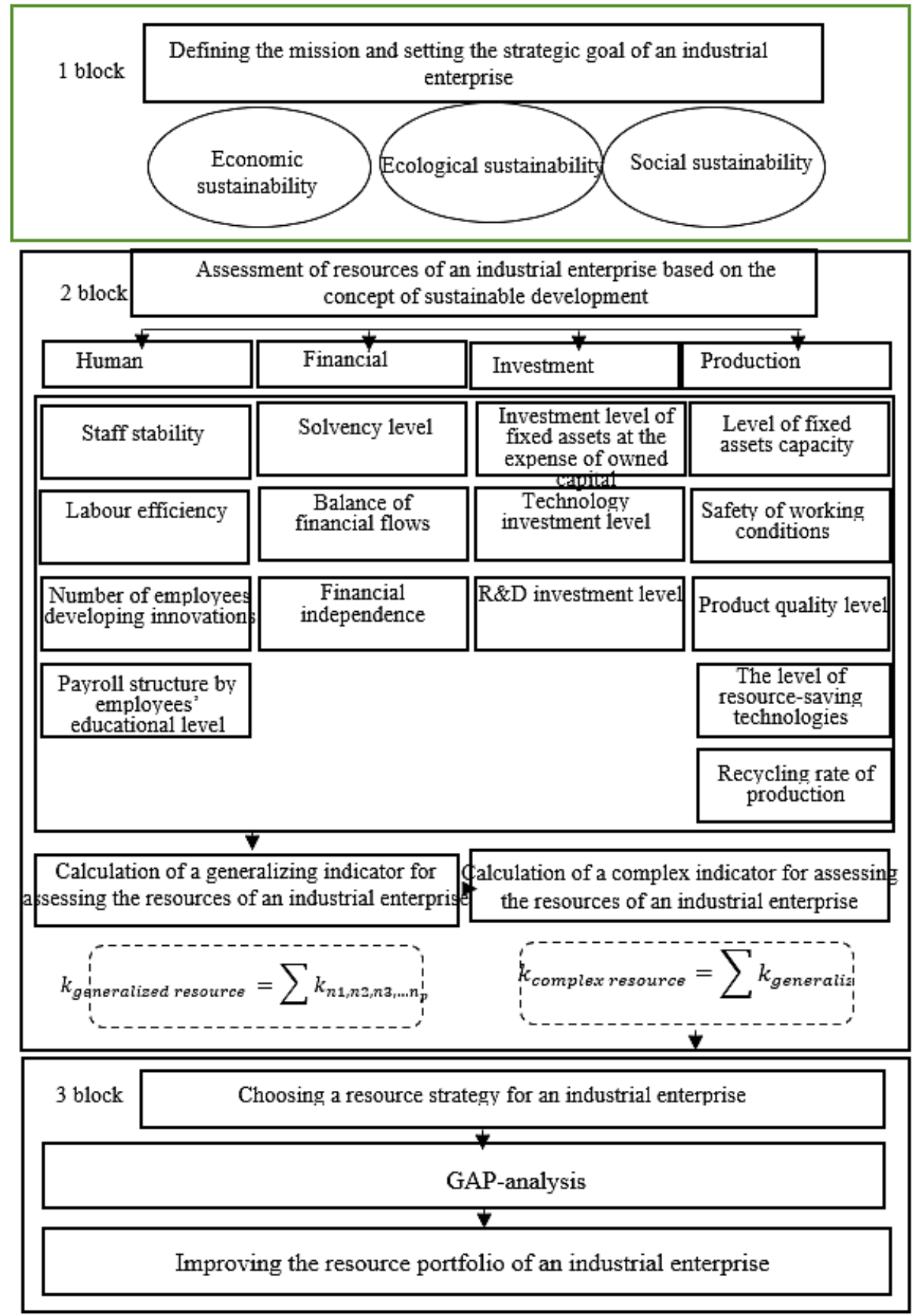

Fig. 1. Stages of forming a resource strategy of an industrial enterprise

The proposed algorithm makes it possible to develop a resource strategy for an industrial enterprise in accordance with the concept of sustainable development. 


\section{Conclusions}

Sustainable development goals are becoming universal and are aimed at improving wellbeing, environmental protection, and social justice. Within the framework of the "Agenda for 2030", the UN in 2015 formed a fifteen-year action plan containing 244 indicators and 17 sustainable development goals. This plan will be implemented by all countries and stakeholders. Decree of the President of the Russian Federation of May 7, 2018 No. 204 "On national goals and strategic objectives for the development of the Russian Federation for the period up to 2024" provides 159 indicators to achieve sustainable development goals.

The basis for the formation of a resource strategy as the foundation of a competitive business model of an industrial enterprise should be a detailed analysis of the resource portfolio of an industrial enterprise. The application of the methodology for assessing the resources of an industrial enterprise based on the concept of sustainable allows:

- to explore human, investment, production, financial resources from the standpoint of achieving sustainable development goals;

- to bring the resource assessment indicators to a single metric;

- to draw conclusions about the effectiveness of the formation and use of resources of an industrial enterprise from the point of view of sustainable development.

The developed methodology for assessing the resources of an industrial enterprise based on the concept of sustainable development makes it possible to choose a resource strategy that takes into account economic, environmental, and social sustainability.

\section{References}

1. A. Guri, S. Guri, A. Aliu, O. Lubonja, Academic Journal of Interdisciplinary Studies, 9, $626(2013)$

2. T.N. Gubaidullina, A.I. Lazarchik, The Kazan Economic Bulletin, №5(13), 107 (2014)

3. O. M. Kryuchkova, A.D. Guzenko, Current State and Prospects, Scientific and Methodological Economic Journal "Concept", 35, 44 (2016)

4. N.N. Kalkova, Journal «Resources, Information, Provision, Competition», 3, 159 (2016)

5. E.O. Wegner-Kozlova, O.M. Guman, Journal of New Economy, 21(4), 28 (2020)

6. P. Nijkamp, F. Soeteman, International Journal of Social Economics https://www.emerald.com

7. S. Renko, The Concept of Sustainable Development, The Sustainable Marketing Concept in European SMEs, Emerald Publishing Limited, Bingley, 29 (2018)

8. A. A. Feil, D. Schreiber, C. Haetinger, V. J. Strasburg, C. L. Barkert, Journal Sustainability, 11, 32 (2019)

9. S.V. Orekhova, Herald of Omsk University. Series: Economics., 1(57), 127 (2017)

10. A. T. Mengistu, R. Panizzolo, Journal Sustainability, 13(10), 8 (2021)

11. S.N. Bobylev, O.V. Kudryavtseva, S.V. Solovyova, Economy of Region Journal, 3(39), 101 (2014)

12. E. Yu. Kuznetsova, O. O. Podolyak, S. V. Kuznetsov, Journal of New Economy, 21(4), $131(2021)$

13. U. Lucia, D. Fino, G. Grisolia, Environment, Development and Sustainability, 14 (2021) 